\title{
Communicative Entrepreneurs: The Case of the Inter-American Court of Human Rights' Dialogue with National Judges
}

\begin{abstract}
This article explains how norms emerge when actors interested in spearheading international norm development are uncertain about how to operationalize new standards of behavior. It shows that lacking an actionable template ready for propagation does not condemn individuals or organizations wishing to challenge and replace existing state practices to irrelevance. I conceptualize "communicative entrepreneurship" as an alternative mode of engagement conducive to norm development under these conditions. Unlike "norm entrepreneurs," communicative entrepreneurs do not project normative or technocratic certainty, but use nudges and networking strategies to trigger debates that define the contours of emerging scripts. I illustrate the argument with the case of the Inter-American Court of Human Rights, which became interested in regulating the use of its jurisprudence by local judges, but lacking a script amenable for diffusion, triggered a dialogue with national courts to jointly regulate citation practices, and more generally, judges' obligations vis-à-vis international human rights jurisprudence. Using original interviews and other sources, I trace the impact of communicative entrepreneurship on the behavior of Mexican and Colombian high courts, and show that it led to the development of new judicial decision-making standards in two very different contexts, bolstering the authority of the Inter-American Court.
\end{abstract}

Acknowledgements: I would like to thank Matthew Broad, Geoff Dancy, Jody LaPorte, Giovanni Mantilla, Kevin Mazur, Rob Schub, Luis Schiumerini, Jazmin Sierra, Duncan Snidal, two anonymous reviewers and, especially, the ISQ editorial team for excellent feedback. Earlier versions also benefitted from comments by participants at the Human Rights Regime Effects Workshop at UCL.

\section{Introduction}

Scholars tend to rely on models of "norm entrepreneurship" to explain how weak international actors promote new standards of appropriate behavior that transform state practices and identities (Finnemore and Sikkink 1998). According to such accounts, shared standards materialize as non-state actors such as NGOs or IGOs spread highly specific technocratic recipes or conceptions of "the good" through persuasion, pedagogy, or shaming (Finnemore 1993; Keck and Sikkink 1998; RisseKappen et al. 1999; Johnston 2001; Goodman and Jinks 2013). Guided by welldefined scripts and clear blueprints that prescribe new behavioral patterns or organizational forms, these transnational activist networks often trigger "norm cascades" that fundamentally change both the way states do things, and ideas about 
right and wrong (Sikkink 2011). Competitive or identity-based emulation processes (Simmons and Elkins 2004; Cao 2010), and the creation of institutions relying on carrots and sticks to deepen socialization (Greenhill 2010), reinforce these cascades.

This article, by contrast, explains how norms emerge when the actors who are interested in spearheading global scripting exercises find themselves in a position of greater uncertainty regarding the content and operationalization of the behavioral, technocratic, or moral standards they would like states to adopt. Lacking an actionable template ready for propagation does not condemn individuals or organizations wishing to challenge and replace existing practices to irrelevance. I identify and conceptualize an alternative mode of engagement conducive to norm development under these conditions: "communicative entrepreneurship."

Communicative entrepreneurs begin by identifying social domains in which they would like to see greater agreement on, and internalization of, standards of behavioral appropriateness. Unlike norm entrepreneurs, however, they do not count with a clear script amenable for diffusion. Consequently, communicative entrepreneurs cannot engage in shaming, pedagogy, or persuasion. Instead, their efforts are geared towards drawing relevant interlocutors into a conversation about how to regulate these domains. Communicative entrepreneurs promote exchanges during which their targets are invited to supply ideas and jointly craft new behavioral standards. They present their project of norm development, and conceive of it, as an open-ended dialogue, and create special venues that provide a leveled playing field conducive to a genuine discussion. Norm development thus becomes a multidirectional, consensual, and participatory process, and acquires a fundamentally horizontal character (Risse 2000; Hawkins 2004; Sandholtz 2008). In other words, while they want to "build community" and promote convergence in behavioral 
patterns, communicative entrepreneurs lack normative or technocratic certainty. Indeed, the do not put forward, let alone harbor, defined visions of how concretely to operationalize new standards. Under conditions of uncertainty, reaching out to others to hear their views is necessary to define the contours of emerging scripts.

The article begins by conceptualizing "communicative entrepreneurship", showing that, in addition to the socialization tactics of norm entrepreneurs, the promotion of dialogue can be an effective source of change in the normative fabric of international society. It then uses the case of the Inter-American Court of Human Rights (IACtHR) to illustrate this alternative type of agency in norm cycles. Like other international courts, the IACtHR became interested in regulating the use of its jurisprudence as a source of law. Lacking a clear script ready for propagation, however, it triggered a dialogue of equals with national judges in order to jointly develop norms of transjudicial communication. Communicative entrepreneurship led to the operationalization of new judicial decision-making standards, increased the IACtHR's influence, and helped put an end to a long history of suspicion and resistance to international law among Latin American high courts.

The use of international jurisprudence by national courts - a form of transjudicial communication - has gained momentum in recent decades (Slaughter 2004; Bahdi 2002; Sandholtz 2015), and is a mark of the growing role of international law in the development of rights-protection standards. The implications are farreaching, not only because it bolsters the impact of international courts in domestic politics, but also because it makes available a language that facilitates progressive rulings by local judiciaries. For example, Argentina's Supreme Court invoked an IACtHR ruling to authorize trials against former dictators accused of crimes against 
humanity. ${ }^{1}$ Colombia's Constitutional Court also relied on Inter-American precedents to define the contours of permissibility for peace talks with armed groups. ${ }^{2}$ Similarly, Mexico's Supreme Court followed IACtHR guidelines to limit the power of military courts, thus exposing officers involved in the "war on drugs" to prosecutions in ordinary tribunals. ${ }^{3}$ More recently, Costa Rican judges relied on Inter-American decisions to affirm the right to non-discrimination on the basis of sexual orientation. ${ }^{4}$ In these and other cases, transjudicial communication made progressive outcomes more likely, empowering hitherto disadvantaged plaintiffs and contributing to the explosion of rights-oriented jurisprudence (Hillebrecht 2014).

There are, of course, domestic factors behind the surge in transjudicial communication, including the constitutionalization of human rights treaties (Huneeus 2016), the creation of constitutional courts (Nunes 2010), inter-court power jockeying (Alter 2001), and strategic litigation (Gonzalez-Ocantos 2016). My goal more simply, is two-fold: first, to show that a consistent use of human rights jurisprudence by national courts partly depends on the development of standards of appropriate constitutional interpretation relative to local judges' international legal obligations; and second, that international courts, acting as communicative entrepreneurs, play an important role in catalyzing this process of norm construction. Before they are able to make use of international jurisprudence, national courts must gain clarity regarding the legal status of this source of law, and adopt rules that operationalize its influence. International courts, naturally, would like to see greater engagement with their jurisprudence, but are also uncertain about how to operationalize the influence of this legal corpus. They therefore find in communicative entrepreneurship an attractive

\footnotetext{
${ }^{1}$ Case Simón (2005)

${ }^{2}$ Case $C-579 / 13$ (2013)

${ }^{3}$ See below.

${ }^{4}$ Case $S C$-CP-22-15 (2015)
} 
mode of engagement because it allows them to deploy non-threatening nudges and networking strategies to jump-start a conversation and disrupt routine practices, with the goal of reaching a common understanding of the conditions under which national judges should consult international rulings. Without these international efforts to steer a discussion, uncertainty on both sides is likely to remain high, leading national courts to sidestep a cumbersome political and technical issue, and either ignore precedents, or use precedents inconsistently.

To trace the motivations, modus operandi, and effectiveness of the IACtHR as a communicative entrepreneur, I rely on an original citation database covering the jurisprudence of 13 national courts, interviews with key players in the Inter-American System, and official documents. I unpack the mechanisms through which communicative entrepreneurship jump-started a productive conversation by leveraging temporal variation in the jurisprudence of two courts with contrasting levels of prior openness to international law: Mexico's Supreme Court, historically wary of external influences, and Colombia's Constitutional Court, historically open to foreign sources of law. The comparison reveals communicative entrepreneurship as the catalyst of a collective scripting exercise despite different initial predispositions to address the issue, and highlights the contributions of local judges to norm development.

\section{Communicative Entrepreneurship}

In 1929, democratic theorist Alexander Lindsay noted that through deliberation "something emerges which each can recognize as embodying the truth of what he stood for, and yet (or rather therefore) is seen to serve the purpose [...] better than what any one conceived for himself" (quoted in Milewicz and Goodin 2016, 3). 
Habermas went a step further, associating the legitimacy of rules with inclusive deliberation: "Only those laws count as legitimate to which all members of the legal community can assent in a discursive process of legislation" (1996, 110). Similarly, Brunee and Toope's interactional theory of law (2010, 24-25) suggests that law becomes authoritative "only when it is mutually constructed." These deliberative understandings of legitimacy help conceptualize pathways to international norm construction that are more consensual and participatory than those depicted in models of norm entrepreneurship, and that do not view the projection of moral or epistemic certainty as a necessary trigger of widespread transformations in states' routine practices and identities. I refer to international actors that adopt a deliberative approach to norm development as "communicative entrepreneurs."

Entrepreneurs promote ideas, activities, and business ventures; communicative entrepreneurs promote discussions. Communicative entrepreneurs are driven by a logic of action akin to what Risse (2000) calls the "logic of arguing." They are in the business of triggering debates that are perceived as highly inclusive, horizontal and participatory, with the goal of reaching common ground justifying behavioral standards for poorly regulated social interactions. To accomplish this, communicative entrepreneurs create venues for open debates. Their actions are underpinned by a noninstrumental form of rationality, which commits actors to deploying good, universalizable reasons to defend their opinions in front of others. Crucially, as in Habermas's social theory, communicative entrepreneurs are fully prepared when instigating debates to submit their views to the force of the better argument (Habermas 1984). They are not motivated by the "logic of consequences" because they do not seek to manipulate discourse in order to impose a pre-determined script. Neither are their actions guided by the "logic of appropriateness," for at this stage, 
norms are still blurry, contested, or simply non-existent, and will be the product of the conversation.

The contrast with "norm entrepreneurs," who feature prominently in agencybased models of norm development, is instructive. First, norm entrepreneurs harbor clear behavioral standards that they seek to propagate. They have "strong notions about appropriate or desirable behavior" (Finnemore and Sikkink 1998, 896). Consequently, their campaigns develop and promote clear operationalization strategies. For example, scholars have documented how NGOs propagate antiimpunity norms by crafting highly detailed legal arguments to facilitate human rights prosecutions (Sikkink 2011; Gonzalez-Ocantos 2016). Other, studying NGOs committed to advancing political equality norms, show they do so by promoting the adoption of legislative gender quotas with specific design characteristics (Towns 2010).

Communicative entrepreneurs, by contrast, lack this conceptual and operational clarity. They seek neither to convince their interlocutors of a deeply held belief, nor to offer a highly scripted alternative course of action. Instead, they aspire to a greater understanding of, and ease with, evolving normative prescriptions. It's not that communicative entrepreneurs lack an agenda; after all, "communicative action serves to coordinate the action of people in order to achieve certain objectives" (Muller 2004:405). But communicative entrepreneurs are usually at a loss regarding how best to accomplish these objectives, and do not always know how to define viable and workable parameters of behavior. Consequently, they reach out to their intended interlocutors in order to instigate talks, share insights, and figure this out.

Second, the central tool of norm entrepreneurs is socialization, which involves drawing others into an existing community bound by specific norms and values 
(Checkel 2001; Percy 2001). Although they sometimes use coercive strategies such as shaming, norm entrepreneurs seek principally to persuade states (Payne 2001). This involves creating discursive frames that link their ideas to those principles that enjoy widespread legitimacy, including universal values (like equality or dignity) that resonate with audiences (Keck and Sikkink 1998, 27; Sandholtz and Stiles 2009). Persuasion is therefore a unidirectional process that transforms the values, priorities, and causal beliefs of targets in line with pre-defined standards (Johnston 2001). Norm entrepreneurs are not willing to submit their views to the force of the better argument; they are convinced theirs is the better argument.

Communicative entrepreneurs operate differently. When communicative rationality, as opposed to persuasion, is what characterizes a social interaction, actors aim jointly to fill in the blanks of otherwise vague behavioral standards, and thus replenish the reservoir of common understandings that facilitate interaction and social integration (Habermas 1984). They may of course fail to reach a consensus, but the goal is to have an open debate that helps define what ought to be done, providing an actionable template acceptable to all. Instead of deploying frames, communicative entrepreneurs instigate debates by provoking responses from their desired interlocutors and creating suitable venues for such exchanges to unfold. They thus raise problem salience and emphasize the need to find solutions. Discursive efforts focus on conveying openness to having discussions in which nobody projects normative certainty and different views are given equal consideration.

Third, accounts of "norm entrepreneurship" posit isomorphism as the ultimate goal, or sign of success (Towns 2010, 24-34). Indeed, "localization" practices are seen as potential signs of norm perversion or resistance (Capie 2008; Acharya 2013). To be sure, communicative entrepreneurs also want to promote convergence in 
behavioral patterns. Unlike norm entrepreneurs, however, they are prepared to accept greater variability in the way their interlocutors operationalize norms. This is a function of the communicative entrepreneurial ethos, which makes such actors willing to submit to the force of the better argument. After all, the better solution may be context dependent; accepting your interlocutors' input, as well as understanding their needs, is likely to lead to the effective legitimation of new standards. Additionally, communicative entrepreneurs understand that normative uncertainty, which encourages communicative entrepreneurship in the first place, makes it difficult to craft, let alone agree on, highly specified and generalizable operational guidelines. In this sense, far from seeing local variability as a perversion, communicative entrepreneurs embrace it as a way to improve the chances of successful norm development in the absence of a ready-made script available for top-down diffusion.

\section{An Application to International Courts}

Communicative entrepreneurship, as a model of norm development, is useful for thinking about how international courts boost the use of their jurisprudence by domestic judiciaries, thereby scripting and routinizing their influence.

Scholars tend to assume that national courts are aware of international law and behave opportunistically, ignoring or citing it depending on the circumstances (Black and Epstein 2007). Citing international legal instruments is thought to be a useful strategy when pursuing a variety of agendas because international law has "persuasive authority" (Martin and Simmons 1998). In particular, since international human rights law and the rights enshrined in domestic constitutions share "substantive normative foundations," judges wishing to enforce those rights naturally rely on international law to bolster the appeal of their decisions (Sandholtz 2015, 608). 
Yet, judges' awareness of international law and jurisprudence, and the obligations these impose on them, cannot be taken for granted. In Latin America, for example, the hegemony of legal positivism throughout the twentieth century meant that citing sources of law other than domestic statutes was perceived as utterly inappropriate (Lopez-Medina 2004; Cepeda 2006; Hilbink 2007; Couso 2010). Until recently, Mexico's Supreme Court even explicitly banned the use foreign precedents (Cortez 2017). Likewise, a survey conducted in Colombia in 1989 showed that only 10 percent of judges knew of at least one human rights treaty (Valencia 1990). Judges interviewed by Gonzalez-Ocantos (2016) in five countries also admitted profound ignorance of international human rights law, even after key treaties were granted constitutional status. And a similar resistance has been documented in post-1945 Western Europe, and Eastern Europe prior to EU-accession (Alter 2001; Müller 2017).

In order to observe high levels of transjudicial communication, judges first have to modify interpretive reflexes nurtured via professional socialization dynamics that lead them to ignore, or be skeptical of, foreign sources of law (Benvenisti 1993). Once ignorance is overcome, the influence of international law has to be operationalized, in order to regulate its use in concrete cases. Although the broad values promoted by a treaty may be clear ("torture is unacceptable"), there is considerable uncertainty surrounding how domestic judiciaries might enforce those values. This ambiguity is especially salient in the case of international jurisprudence. In Europe, for instance, there is huge variability in how courts interpret the status of the jurisprudence of the European Court of Human Rights (Müller 2017). Crucially, most treaties and constitutions remain silent on whether national judges have the responsibility to render decisions that take into account international rulings. Do these 
precedents apply to all parties to the treaty, or just to the plaintiffs? Are provisions mandatory, or simply advisory? (Voeten and Helfer 2014)

In the absence of clear rules that operationalize the effects of international jurisprudence in domestic law, the robustness of transjudicial communication is likely to suffer because local courts will either ignore precedents or use them in inconsistent ways. By contrast, a successful scripting exercise is bound to systematize the influence of international courts. But how do new norms of transjudicial communication develop, in turn transforming decision-making routines? "Communicative entrepreneurship" provides useful tools for understanding how international courts might expand judges' tool-sets, promoting the habit to consider international jurisprudence.

First, dialogue can develop new standards because the aforementioned uncertainty surrounding the legal status of international jurisprudence also affects international courts. International courts cannot simply dictate operational standards applicable to all courts under their jurisdiction, for domestic judges work in heterogeneous institutional environments. General solutions based on a formalistic understanding of the relationship as strictly hierarchical are hence unlikely to work across countries (Shany 2007). Moreover, national judges may rebel against this imposition, or decide to delegate harmonization to international courts, in both cases continuing to rule as they see fit. To further complicate matters, international courts, especially human rights courts, tend to rule on exceptional cases. The relevance of this jurisprudence for the daily work of domestic courts is far from clear, making it difficult to extract general decision-rules.

Due to the uncertainty surrounding this issue domain, international courts cannot behave as "teachers of norms" (Finnemore 1993), for this presupposes clarity 
about those principles one intends to disseminate. International courts must therefore rely instead on alternative mechanisms to increase their influence over judicial practices. Specifically, a dialogic approach to legal construction is bound to be productive, because taking into account the insights of domestic courts enables international courts to proffer solutions to the problem of the status of international jurisprudence bound to work best in contexts with varying political and constitutional constraints. A two-way flow of information and ideas increases the likelihood that informative, viable, and acceptable operational standards emerge, disrupting local jurisprudential inertia and plugging the normative gap.

Second, regardless of the availability of ready-made operational rules, international courts have a limited capacity to force states to take them seriously. A robust transjudicial communication is unlikely to emerge from a top-down process through which international courts compel domestic judges to systematically use their jurisprudence via sanctions. An international human rights court can, for example, conceivably shame a state into implementing a specific decision, but it can hardly force a Supreme Court to accept its pronouncements as routine compulsory reference points. Indeed, the politics of regulating the authority of international precedents are bound to be more complex, than, say, the politics behind the development of standards regulating treaty citations, simply because international jurisprudence is more threatening for local judges. By applying treaties to concrete cases, international court rulings inevitably reduce the degrees of freedom for treaty interpretation available to local courts. These degrees of freedom are otherwise quite generous (Sandholtz 2015). Furthermore, acknowledging the authority of international jurisprudence risks upsetting the hierarchy of the domestic legal order. Among other 
things, it gives lower courts a platform from which to justify deviations from high courts' criteria (Alter 2001).

In light of these tensions, it is not surprising that local courts often prefer a loosely regulated relationship with international jurisprudence, as this affords them greater latitude to invoke precedents opportunistically. If international courts are to avoid negative reactions and promote tighter behavioral scripts that lead to a consistent engagement with their jurisprudence, they must temper this resistance. To do so, they must proceed in ways that nurture self-policing impulses among national courts. This can be achieved via communicative entrepreneurship, recognizing the input of local judicial actors in the process of establishing norms about weather, and under what conditions, international jurisprudence can/must be invoked as a valid source of law.

\section{Mechanisms of influence}

How do communicative entrepreneurs instigate norm development? First, communicative entrepreneurs deploy nudges. Nudges are not "mandates" or explicit behavioral scripts (Thaler and Sunstein 2008, 6), but subtle interventions that disrupt behavioral inertia by transforming choice architectures. In so doing, nudges invite audiences to think differently about the options at hand, rattling them with challenging questions and problematizing taken-for-granted habits. The disruptive and non-prescriptive character of nudges is helpful to elicit responses from unreflective or uninterested interlocutors. In the case of communicative entrepreneurs, nudges allow them to call attention to poorly normed social interactions and lure relevant interlocutors to participate in the creation of new behavioral scripts. 
The nudges deployed by communicative entrepreneurs are likely to vary across political/social domains. For international courts seeking to trigger discussions about both the legal status of their jurisprudence and the obligations that arise from it, nudges are usually embedded in rulings aimed at national judiciaries. To call the attention of judiciaries, international courts avoid the usual practice of addressing the "state" as a unitary actor and write rulings that send signals to local courts, treating them as distinct entities. The goal is to open a formal channel of communication that transforms the choice architecture of local judges and interrupts business as usual.

For example, nudges can trigger a dialogue by increasing the salience of intercourt citations as a viable opinion-writing tool. One option is to use national jurisprudence as a source law. This signals the presence of shared concerns/values, shows consideration for the ideas of local courts, and generally indicates that transjudicial communication is not a hierarchical phenomenon but a tool for the collective construction of legal standards. From the perspective of national courts, these references can be a source of pride, and will promote communication as a vehicle to exert broader influence. While citations may soften resistances to start a dialogue, other nudges can more directly trigger a conversation about the uses of international jurisprudence. International courts may therefore find it more useful explicitly to mention that international jurisprudence creates responsibilities for national judiciaries, thus compelling local judges to respond in order to define what those responsibilities are. Mentioning judges as subjects of international legal obligations increases the likelihood that local courts will not see compliance as a foreign policy issue to be dealt with exclusively by the executive, as it has traditionally been the case (Benvenisti 1993). At a more practical level, it ensures that judges are formally notified of international rulings. Importantly, when acting as 
communicative entrepreneurs, international courts do not provide a clear operationalization of these responsibilities; they simply provoke by arguing that those responsibilities exist.

Second, communicative entrepreneurs network. Investing in the creation of spaces to discuss face-to-face the possibility of coming up with new behavioral scripts allows communicative entrepreneurs to engage their targets directly. For example, international courts often visit countries to meet with members of the legal field. When acting as communicative entrepreneurs, they leverage these meetings to showcase the existence of a community of practitioners united by a commitment to common legal instruments (Helfer and Slaughter 1997), lobby local judges about the merits of engaging with international jurisprudence (Helfer and Alter 2009), and follow-up on the jurisprudential "nudges." When they manage to draw judges to intimate venues, international courts find ample opportunities to have open conversations, intensify informational flows, and ultimately achieve greater operational certainty regarding the legal status of international precedents. During these encounters, international courts modify their own views, show deference to their peers, and thus provide local judges with additional incentives to participate in the dialogue.

In the next sections I show that the IACtHR deployed communicative entrepreneurship to great effect, using nudging and networking to offer local courts a level playing when regulating transjudicial communication.

\section{Launching an Inter-American Conversation}


The IACtHR was established in 1969 under the aegis of the Organization of American States, and began operating in the 1980s. ${ }^{5}$ With headquarters in Costa Rica, and jurisdiction over 20 countries, it decides on cases in which states are accused of violating the American Convention on Human Rights and adjacent treaties (Pasqualucci 2013). The IACtHR has faced several institutional challenges. For example, two countries - Trinidad (1998) and Venezuela (2012) - withdrew permanently from the Court's jurisdiction. Its budget is also minimal. In 2016, only 53.55 percent of its meager U\$S 5,147,157.23 budget was covered by the Organization of American States; the remainder came from voluntary contributions. Compounding things further, the IACtHR has no ministerial body like the Council of Europe, which in this case helps the European Court of Human Rights monitor compliance. It is therefore not surprising that the IACtHR's compliance record is poor (Hawkins and Jacoby 2010; Huneeus 2011; Hillebrecht 2014). Finally, rules of standing are very restrictive, limiting the size of the docket and, by implication, the scope of the Court's agenda.

The IACtHR's limited influence over the behavior of national courts has always been a particularly pressing challenge for the development of coherent human rights protection standards across the region. This is in part because the Court lacks treaty-based channels such as Article 177 of the Treaty of Rome, which played a key role in establishing the authority of the European Court of Justice among local judges (Burley and Mattli 1993). True, the IACtHR initially cemented its reputation as a bulwark against impunity by advancing a robust set of standards on access to justice. It also successfully consolidated clusters of rulings on topics such as indigenous

\footnotetext{
${ }^{5}$ For a uniquely comprehensive study of the Inter-American System of Human Rights, see Engstrom (2018).
} 
rights, reproductive rights, and freedom of speech. Until the 2000s, however, the use of this jurisprudence by national courts was negligible (Figure 1).

Figure 1. Citations of IACtHR rulings (1994-2012)

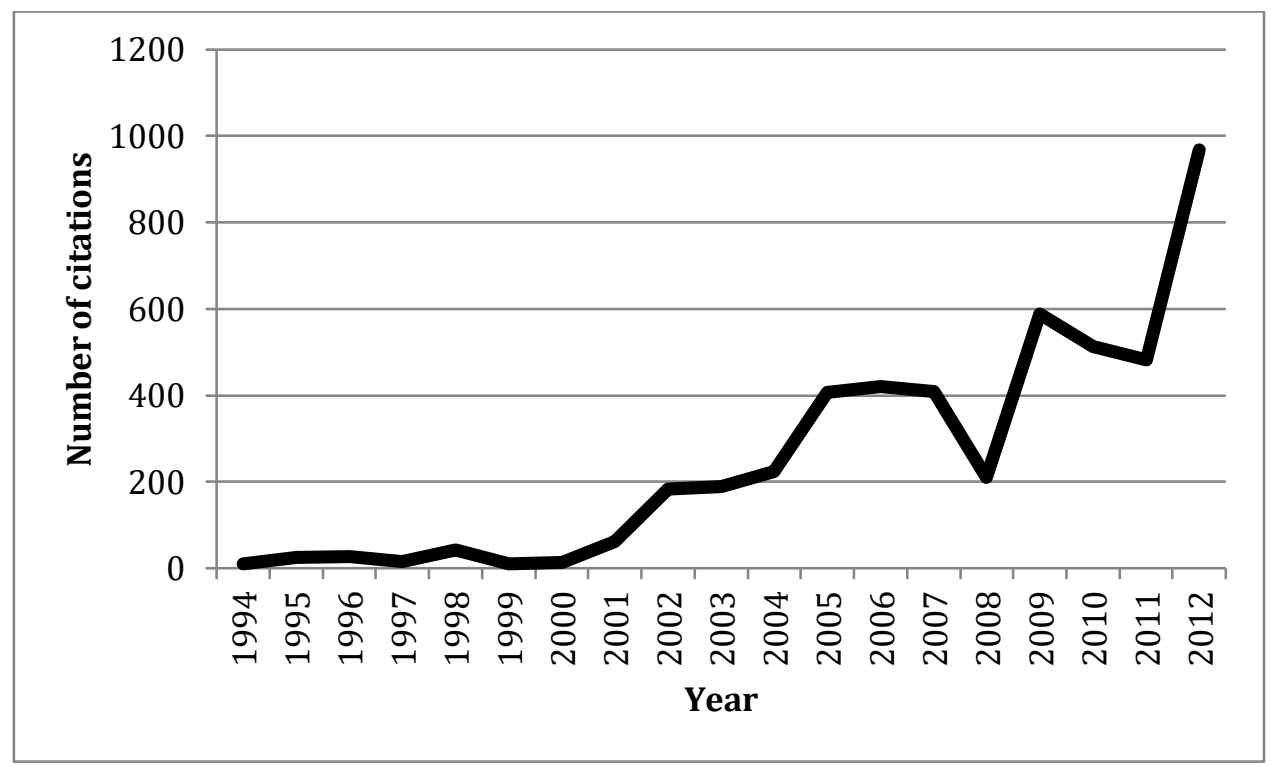

Note: Includes the jurisprudence of the Supreme Courts of Argentina, Brazil, Chile, Costa Rica, El Salvador, Mexico, Panamá, Paraguay and Uruguay, and the Constitutional Courts of Colombia, Ecuador, Guatemala and Peru.

Around the turn of the century the IACtHR became aware of this "impact deficit," reaching the conclusion that its jurisprudence would not automatically translate into greater influence over domestic courts. It therefore began to consider the need to spark a transjudicial dialogue about the international legal obligations of national judges. But in light of the historic resistance to international law among Latin American judiciaries, the IACtHR had to approach the issue with great care so as to generate goodwill prior to beginning discussions about developing norms concerning the influence of this source of law over judicial-decision making. According to a former clerk:

The issue of impact was a central concern [...] Resources were scarce and we received few cases, so it was really important to find other ways of generating 
impact $[\ldots]$ Impact meant being cited more and more often. We had to engage national judges. ${ }^{6}$

Increasing citations was a first step to boosting awareness of the Court, and ensuring "that we are no longer in the 1990s when our jurisprudence was virtually unknown."” The IACtHR believed that more citations would lead to the institutionalization of new judicial habits compatible with stronger rights-protection standards. In the words of a former judge:

[I]nternational courts can't replace states when it comes to compliance. If we are to see human rights respected [...] we must contact our national counterparts to start a dialogue [because they] are the ones that can most directly apply [the Convention]. States comply [.... because someone within the state pushes in that direction [...] That's why we care about being cited. ${ }^{8}$

The IACtHR, though, lacked a clear vision about how to regulate the use of its jurisprudence by local courts. Top-down diffusion of ready-made behavioral scripts, following a norm entrepreneurial model, was thus a non-starter. The Court therefore began to behave as a communicative entrepreneur, using its rulings to nudge domestic judges in ways that put on the table previously ignored questions about the authority of international jurisprudence. While since its inception the IACtHR consistently argued that state practices contrary to the Convention were invalid, prior to the mid2000 s it had never referred to the role of judges in policing incompatibility. ${ }^{9}$ Its rulings had instead addressed the state as a unitary actor, failing to build specific bridges with judicial constituencies to clarify their duties. This changed when the

\footnotetext{
${ }^{6} 11$ March 2016

${ }^{7}$ Former IACtHR Judge, 7 May 2016

84 May 2016

${ }^{9}$ OC 14/44 (1994); Barrios Altos v. Peru (2001)
} 
Court introduced the idea of the "conventionality review," first in Judge GarcíaRamírez's vote in Myrna Mack v. Guatemala (2003), and later in the majority's decision in Almonacid v. Chile (2006). Consistent with the use of nudging by communicative entrepreneurs, the IACtHR coined a term which made the issue an unavoidable topic of conversation and quickly became the focal point of debates about how national courts ought to deal with Inter-American jurisprudence:

[J]udges, as part of the state apparatus, are also subject to [the American Convention] [...] The judiciary must exercise a type of "conventionality review” [of] internal juridical norms [...] In doing so, the judiciary must not only take into account the treaty, but also interpretations rendered by the InterAmerican Court. ${ }^{10}$

This vague enunciation of what the Court hoped would become a new behavioral standard reflects the inability of Inter-American judges to provide a more specific formula to operationalize the "conventionality review." In fact, the IACtHR saw this as the beginning, not the end, of a conversation. Some observers, however, misunderstood its intentions, characterizing the proposal as a move to impose the supremacy of Inter-American law, and not as an invitation to talk (Dulitzky 2015). In a region only starting to get used to the review of constitutionality, the idea that judges ought to also check the "conventionality" of laws sounded, understandably, quite radical. Aware that being perceived as a top-down entrepreneur of strict standards of behavior could hamper the development of a productive relationship with domestic courts, the IACtHR quickly clarified its "communicative" intentions. The message therefore became one where national courts should only exercise the

\footnotetext{
${ }^{10}$ Almonacid v. Chile (2006)
} 
conventionality review within the "boundaries for their own prerogatives." 11 Judge García-Ramírez was particularly keen to highlight the importance of rejecting rigid interpretations, allowing utmost respect for differences in national constitutions and judicial structures. The Court made it clear that the doctrine was not a ready-made template for action, but an opportunity to discuss how to apply Inter-American jurisprudence in diverse contexts.

Interviews with judges suggest that they saw themselves as communicative entrepreneurs. They doubtless understood the perils of overreach and, crucially, lacked a clear vision of how to operationalize the conventionality review. According to one judge:

[C]ommentators made extremely generous interpretations of the meaning of the doctrine, so we clarified our intentions [...] The Court wanted to provoke national courts, but didn't know exactly what the specific parameters of use should be. Those had to be established by national jurisprudence. ${ }^{12}$

The doctrine, in this interpretation, was therefore nothing more than a catch phrase, a nudge used to remind "judges that they too had to abide by the Convention." ${ }^{13}$ In other words, the conventionality review was not part of a pedagogical effort:

Our message to local courts was that they ought to take the jurisprudence of the IACtHR into account, but always decide using the instruments that provide the best possible protections for the rights in question. These may or may not be found in international law [...] The development of the doctrine was an effort to get judges to pay attention to the Convention [...] But the goal was not a pedagogical one. When we began to experience jurisdictional conflicts

\footnotetext{
${ }^{11}$ For a list of relevant rulings, Ferrer-MacGregor (2015).

125 September 2016

${ }^{13}$ Former IACtHR Judge, 4 May 2016
} 
between Supreme Courts and the IACtHR, we thought this doctrine would allow us to find a solution. ${ }^{14}$

Two other judges also emphasized the importance of projecting uncertainty:

There isn't certainty about which are the rules that judges should follow to incorporate international law [...] Here is where we find the debate around the conventionality review. This doctrine is still in the making [...] The only thing that the conventionality review tells judges is that they must use international law. How? Well, each one must do so mindful of the rules regarding the distribution of prerogatives within their respective states. There is more than one valid technique of legal integration. ${ }^{15}$

Our job has been to reassure local judges that the conventionality review does not trump the judicial prerogatives established by national constitutions. ${ }^{16}$

Promoting a horizontal dialogue was an appealing way to engage national courts. Inter-American judges, unable to launch a crusade to impose clear standards of judicial behavior, used communicative entrepreneurship to signal both that domestic courts were crucial to crafting new norms and that they were willing to delegate the final word to their interlocutors. After all, as a former clerk mentioned, local judges were in a position to ignore the IACtHR if they regarded its doctrines as intransigent. ${ }^{17}$ This is exactly the way communicative entrepreneurs operate: they project uncertainty and show willingness to submit their views to the force of the better argument.

\footnotetext{
${ }^{14}$ IACtHR Judge, 6 June 2016

${ }^{15} 10$ August 2016

169 June 2016

1715 September 2016
} 
Further evidence of the IACtHR's normative uncertainty, and its willingness to jump-start a truly participatory exchange, can be found in its networking efforts during the 2000s. The record indicates that between 1980 and 2014 the Court organized 449 outreach activities. These included: interactions with local judges during seminars, official visits, and the signature of inter-institutional accords; academic events to discuss Inter-American jurisprudence; and official visits by heads of state and representatives of international organizations. As shown in Figure 2, academic events and meetings with judges were non-existent during the first 15 years of the series. By 2014, however, they had grown to become as, if not more, common than political contacts. This trend is contemporaneous with the development of the conventionality review, which created a fertile discursive focal point for these face-toface interactions.

Figure 2. Activities organized by the IACtHR (1980-2014)

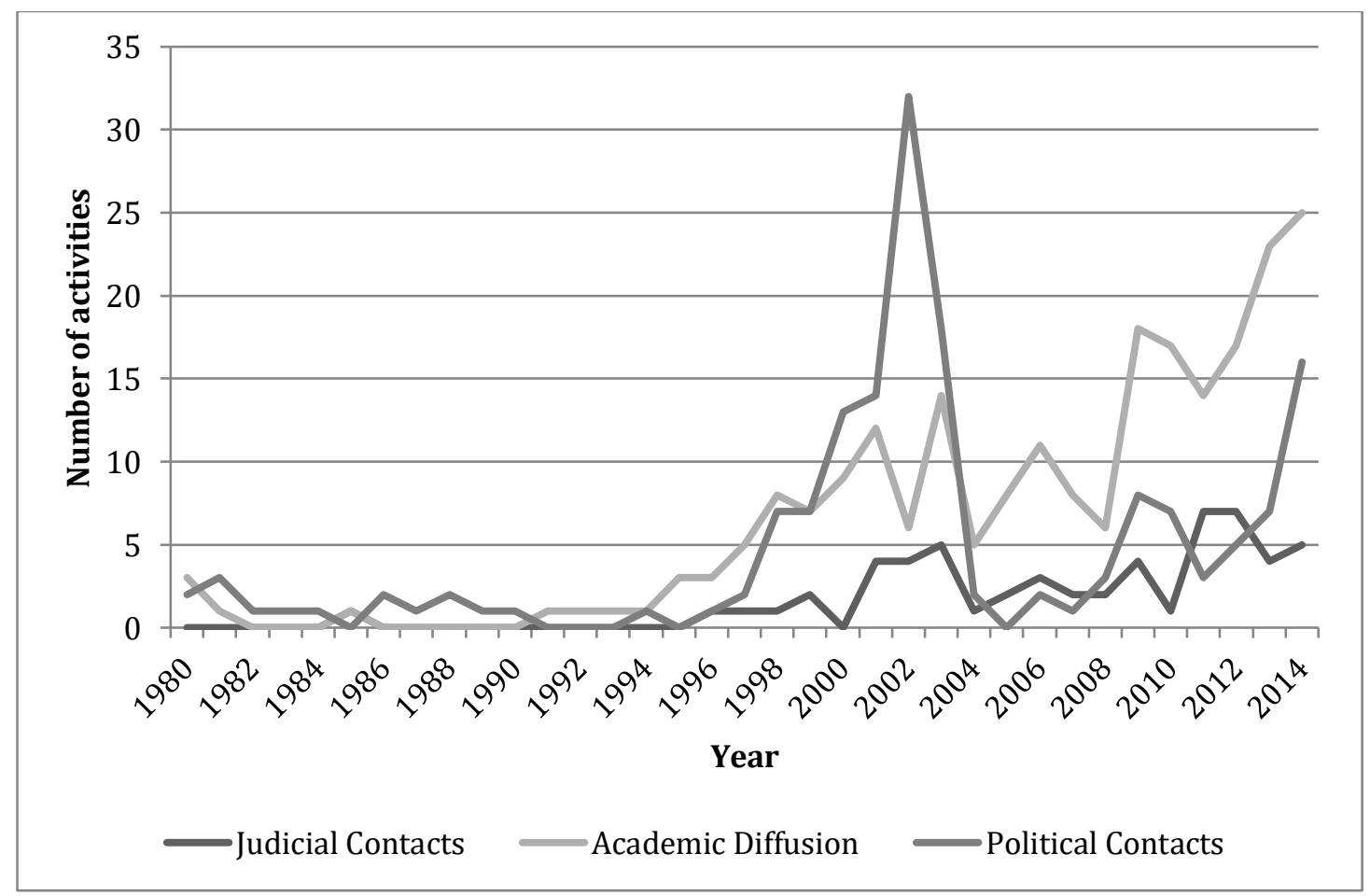

Source: IACtHR Annual Reports. 
Two examples of networking illustrate the IACtHR's modus operandi. One is in the early 2000s, when the Court began to attract external funding that in turn strengthened its capacity to interact with local judges. Most notably, the money was used to organize hearings away from its headquarters, thus enabling closer contacts with domestic actors. As a judge explained, "when we arrived in those countries, judges, lawyers' professional associations, everyone was interested in meeting with us." ${ }^{18}$ These trips raised the profile of the IACtHR and compelled several local courts to seek closer institutional ties, leading to the signature of cooperation agreements that included the possibility of sending clerks to its Costa Rica headquarters so that they could study Inter-American jurisprudence.

Another example relates to how the Court sought the support of the Konrad Adenauer Foundation (KAF) to build bridges with national judges. To this end, in the mid-2000s it began to participate in the KAF's regional summits of high courts. ${ }^{19} \mathrm{~A}$ KAF officer, involved in developing the partnership, described both the IACtHR's reasons for joining the network and the venues created to promote dialogue:

The IACtHR had great interest in talking to supreme and constitutional courts because it realized that its legitimacy depended on the goodwill it could generate among local judges [...] [The] summits offered the perfect environment to start this dialogue $[\ldots]$ because these are closed seminars $[\ldots]$ As a result judges could openly exchange points of view.

The IACtHR thrived in this context, approaching local judges in non-threatening ways and collecting valuable information:

It was absolutely essential that the judges got to know each other personally [...] Both had to realize they were dealing with reasonable people, capable of

\footnotetext{
${ }^{18}$ Judge, 6 June 2016. These meetings are not included in Figure 3, so the graph underreports "judicial contacts."

${ }^{19}$ KAF Officer, 18 August 2016
} 
putting together cogent arguments. [For the IACtHR] it was crucial to generate the impression that the conventionality review was not part of a power play, and that any controversy surrounding it was simply a matter of different opinions [...] The network allowed the Court to take the pulse of national judiciaries [...] It's important that an international court knows how to measure its strength and legitimacy, and to know when it can push for certain processes and when to act prudently. ${ }^{20}$

Other testimonies reinforce the point that networking allowed the IACtHR to present itself as a non-threatening actor willing to promote the participation of local courts in horizontal discussions. According to a former clerk, "for some InterAmerican judges it was very important to start a personal dialogue with local courts to explain their goals and intentions, and expose themselves to criticisms." ${ }^{21}$ Judges exploited this intimacy to project openness to ideas that could help them clarify the contours of the conventionality review: "face-to-face our judges are better able to put forward a moderate vision of the conventionality review, one that generates fewer frictions." 22

It is of course difficult to reconstruct precisely what happened during these informal exchanges or whether ideas indeed flowed. But the testimonies of some participants do hint at how horizontality played out:

I met in private with high court judges. One of them told us that she was happy to abide by the Convention, but not by the Court's jurisprudence. So we argued. When we talked about the conventionality review I told them that it didn't mean that they had to directly apply all rulings. I clarified that they had

\footnotetext{
${ }^{20} 21$ September 2016

2111 March 2016

${ }^{22}$ Clerk, 15 September 2016
} 
to analyze each precedent to see if they could be useful to solve specific cases [...] [In another country] we also met in private with some judges and gave them ideas on how to [comply with our jurisprudence]. But we also asked them for ideas on how to approach a judgment we were drafting at the time. This kind of deference is crucial. ${ }^{23}$

Another judge also characterized these meetings as a two-way street that helped shape of the conventionality review doctrine:

We wanted to trigger an exchange. An exchange means that ideas should circulate both ways $[\ldots]$ To the extent that national high courts were producing important innovations, we wanted to be able to learn about those rulings $[\ldots]$ These meetings also produce interpersonal exchanges that thaw relationships with reticent courts, allowing us not to persuade, but to explain our motives. This is what happened with the Uruguayan court after the 2011 Gelman decision. $^{24}$

The timing of the IACtHR's efforts to hook local courts to a conversation matches the overall evolution in citations, which is suggestive of some level of impact. Importantly, the upward trend that began in the mid-2000s, when the Court launched the conventionality review, is observed both among courts that were already open to international law (e.g. Colombia, Costa Rica, Argentina), and courts that had hitherto resisted external legal influences (e.g. Mexico, Brazil, Uruguay). ${ }^{25}$ Communicative entrepreneurship played a catalyzing role in developing new norms of constitutional interpretation regardless of this initial predisposition. To illustrate

\footnotetext{
${ }^{23}$ IACtHR Judge, 10 August 2016

${ }^{24} 5$ September 2016. Gelman nullified Uruguay's amnesty law. At first, judges refused to comply. They changed their minds after meeting the IACtHR. A lawyer who witnessed the exchange confirmed this (Interview, 12 September 2016).

${ }^{25}$ See Appendix
} 
how this happened, and show how greater attention to Inter-American rulings had substantive consequences for the development of rights protections, I trace the impact of nudging and networking at the local level in countries belonging to these two groups. First, I look at how the IACtHR disrupted longstanding decision-making patterns in Mexico, luring reticent and ignorant judges into a productive discussion about the status of international jurisprudence. Second, I turn to Colombia where, despite greater openness to international law, communicative entrepreneurship also played a role in regulating the influence of human rights jurisprudence. The IACtHR triggered an intense discussion which led to the development of more detailed behavioral scripts than those the Constitutional Court had been willing to produce on its own.

\section{Mexico}

Prior to 2006, the Mexican Supreme Court had never cited the jurisprudence of the IACtHR. In the following six years, however, the citation count rose to 325, putting Mexico in fourth place in the overall ranking of Latin American courts. This temporal change in judicial habits is puzzling because Mexico's Supreme Court is famous for its history of resistance to foreign sources of law. The change in trajectory can be explained in large part by the communicative entrepreneurship of the IACtHR, which thus influenced a "least likely" case.

During the PRI regime the Mexican judiciary was an appendix of the presidency (Magaloni 2008). This began to change in the 1990s when the ruling party strengthened the autonomy of the Supreme Court by giving it original jurisdiction in matters raised by legislatures, parties, and governors. This transformed the Court into a referee in disputes between the branches of the federal government, and between 
levels of the federation (Magaloni 2003). Despite these changes, the Supreme Court still lagged behind the regional trend towards more robust rights-protecting jurisprudence (Ansolabehere 2010). This is often attributed to a rigid view of the constitution: judges still favored plain-meaning interpretation and did not see it as their duty to expand the content of rights by interpreting the constitution creatively, in light of, for example, international human rights law. According to this rigid version of formalism, the law involves a set of unequivocal, non-complementary written rules, leaving little room for judicial interpretation. For example, Article 133 of the constitution incorporates international law into the legal system, but Supreme Court precedents historically downgraded its status. The testimony of a former Supreme Court judge summarizes a legal philosophy that fails to encourage judges to think about the compatibility of laws with fundamental rights, and leads them to think of constitutionality tests in purely procedural terms:

Our role $[\ldots]$ is to read the Constitution, not to say what I would like the Constitution to say. This position $[\ldots]$ reduces the court to a technical role [...] We must establish what is technically correct given what the Constitution says. We are not here to say if a law is good or bad. ${ }^{26}$

The pervasiveness of formalism was partly a legacy of authoritarian rule. During the era of one-party rule, Supreme Court jurisprudence was meant to strictly regulate legal interpretation, discipline lower courts, minimize their ability to discretionally interpret the law, and make them perfect agents of the regime. By promoting an extreme version of formalism, and engraining rigid interpretative routines, the system stifled judicial power (Magaloni 2007). The judiciary itself also failed to reward innovative behavior. A Supreme Court judge reflects on how difficult 
it is to disrupt the reproduction of these problem-solving templates: "There is an institutional inertia that determines attitudes and ways of reading the Constitution and our main laws. It is hard to overcome this longstanding way of understanding the role of the judiciary. ${ }^{" 27}$ Formalistic routines also limited judges' knowledge of alternative sources of law. For example, when asked why in famous forced disappearance cases the Supreme Court virtually ignored seminal Inter-American jurisprudence, another justice explained:

The opposition to other ways of thinking about and reading the law has a lot to do with ignorance. The fact that the 2003 [Supreme Court] ruling on forced disappearances does not mention any international legal instruments is the product of ignorance [...] In Mexico we have members of the Supreme Court who are very formalistic. ${ }^{28}$

What explains the change in citation practices? New personnel doubtless played a role. The arrival of Justice Cossío in 2003 for one broke with the tradition of promoting existing judges to the Supreme Court, allowing for the influx of fresh ideas compatible with a transjudicial dialogue. Before joining the court, Cossío was a law professor at a private university that promotes a more modern approach to law than the Autonomous National University, the traditional incubator of judges. In addition, Cossío had completed a doctorate in Spain under the supervision of influential neoconstitutionalist jurists. In time, Cossío became aware of the importance of resocializing judges to deinstitutionalize certain decision-making routines and, thus, to open the judiciary to international law:

\footnotetext{
${ }^{27}$ Personal correspondence.

283 September 2010
} 
Mexican lawyers do not cite [international jurisprudence]. Many judges do not know about these things because they have simply not encountered them before. This Court should start doing it, but for the most part it doesn't know how to, which means we have to re-train our lawyers. ${ }^{29}$

To help implement this modern vision of constitutionalism, he recruited clerks educated abroad who were also judicial outsiders. Their mission was to disrupt the formalistic instincts typical of Supreme Court jurisprudence. As one explained:

We began to include references to international law in the draft opinions we shared with other judges. We had the crazy idea of throwing everything in $[\ldots]$ so that at least some of those references would stick [...] I have a file with a list of Inter-American rulings, indicating which rights are discussed in each case. I've distributed it among my colleagues so that they can use it too. ${ }^{30}$

Resistance to modify longstanding routines, however, remained strong, with there being various internal barriers to change. As a condition to join Cossío's opinions "other judges usually told us to remove some or most of the citations." 31 Another clerk similarly admitted that, for many of her colleagues, trudging the jurisprudence of the IACtHR was like "going to Mars." ${ }^{32}$ Little wonder, then, that by 2010 just 38 of the 159 references to Inter-American jurisprudence found in Supreme Court rulings belonged to decisions drafted by judges other than Cossío.

While Cossío's changes did begin to expose the Court to international standards, they were alone insufficient to guarantee a robust transjudicial dialogue. Crucial in this regard was the communicative entrepreneurship of the IACtHR. First,

\footnotetext{
2915 July 2010

${ }^{30} 24$ September 2010

31 Ibid.

3210 August 2010
} 
the IACtHR deployed networking strategies. For example, it took advantage of its connections with the Mexican branch of the KAF, which was staffed by officers responsible for spearheading the regional network described in the previous section. As organizers of the "Working Group on Constitutional Justice," which included Inter-American judges and academics with strong links to the Mexican judicial establishment, KAF officers were uniquely positioned to connect both courts. In addition, one of the members of the group had clerked in the Supreme Court, and was now affiliated to the Instituto de Investigaciones Jurídicas, an institution that played a crucial role in the development of the conventionality review doctrine. These ties, and the geographical proximity of the actors, allowed the IACtHR to cultivate strong bonds with the Supreme Court, and introduce its ideas. An important institutional outcome of these contacts was the creation of an internship program that allowed Mexican clerks to spend time in Costa Rica. Between 2005 and 2012 at least 9 made use of the scheme (Cortez 2017).

Second, the IACtHR made use of jurisprudential nudges. Indeed, Mexico's Supreme Court did not seriously debate the status of Inter-American jurisprudence until the IACtHR put the issue on the table in Radilla v. Mexico (2009). Nudging lured Mexican judges into thinking systematically about how to define the parameters of use of international case law, thus triggering a conscious effort to operationalize a radical change in the Court's interpretive routines. This in turn catalyzed a rise in citations.

In Radilla the IACtHR ordered Mexico to investigate a forced disappearance that took place in 1974. Crucially, the ruling invoked the conventionality review to remind Mexican judges of their responsibilities under international law, inviting them to adopt more demanding standards when addressing rights violations. Importantly, 
unlike previous decisions against Mexico, this one unequivocally mentioned the judiciary as one of its intended interlocutors. When comparing the reaction of the Supreme Court to this and previous IACtHR rulings, it is clear that the nudging employed in Radilla played a role in jump-starting a conversation. As a clerk privy to the internal debate explained, "Campo Algodonero v. Mexico [NB. an earlier ruling] didn't make much noise inside the Court. It never mentions the federal judicial branch [...] Radilla is different: it called the attention of the Court." ${ }^{, 33}$

The Supreme Court began to discuss Radilla in $2010 .{ }^{34}$ Initially, the judges had a protracted debate about whether they should hear the case at all. The tone of the debate showed how disconcerting it was to discuss the possibility of transforming interpretive routines. ${ }^{35}$ According to a clerk with access to these deliberations, "the idea that they had to discuss the implications of an international ruling against Mexico, and comply with it, were not things that fell within their legal horizons." ${ }^{, 36} \mathrm{~A}$ majority eventually agreed to address the issue, and in July 2011 handed down a landmark ruling stating that judges must exercise the conventionality review. ${ }^{37} \mathrm{~A}$ clerk explained why the court responded to the nudge:

They were able to moderate the impact of the IACtHR, and explain the way in which Mexican judges should apply a part of the legal order over which Supreme Court judges have no control. It was a way of internalizing the external juridical problem. ${ }^{38}$

\footnotetext{
${ }^{33} 29$ September 2010

${ }^{34}$ By giving the IACtHR greater visibility, the rulings intensified networking efforts. KAF Officer, 21 September 2016.

${ }^{35}$ Transcripts: https://www.scjn.gob.mx/pleno/Paginas/ver taquigraficas.aspx

3612 June 2014.

37 912/2010 (2011)

38 16 June 2014
} 
The timing of the nudge also increased its effectiveness: while the Supreme Court debated Radilla, Congress amended the constitution to elevate the status of human rights law. This too demanded a response:

It was necessary to build a narrative that explained these changes $[. .$.$] Lower$ court judges were anxious to hear what these changes meant for them $[\ldots]$ This is what strengthened the position of the majority, because it was clear that the Court $[\ldots]$ could not remain silent. ${ }^{39}$

Put another way, the Supreme Court found it in its institutional interest to acknowledge the IACtHR as a valid interlocutor and to regulate the response of lower courts' to a new paradigm of judicial reasoning implied in the conventionality review doctrine. This would avoid a breakdown in the judicial chain of command.

Communicative entrepreneurship forced a dialogue by intensifying the debate within the court. At the same time, however, the vagueness of the conventionality review doctrine left enough space for the Supreme Court to micro-manage the influence of international jurisprudence. Indeed, far from being passive listeners, Mexican judges used this and other rulings to operationalize the doctrine in ways that reduced the threat of international law and appeased internal divisions.

For the formalist camp, mandating lower courts to rule in light of InterAmerican precedents represented a threat to constitutional supremacy and an affront to legal sovereignty. Furthermore, allowing judges freely to integrate different legal frameworks would result in disparate readings of Mexican laws. ${ }^{40}$ Judges in the majority, by contrast, called for the adoption of dialogic hermeneutic practices in which no source of law automatically outranked the other. Their understanding of the conventionality review was in line with the IACtHR:

\footnotetext{
${ }^{39}$ Clerk, 12 June 2014

40 912/2010 (2011)
} 
[National courts] are in a constant dialogue with the international court [...] It is not the case that the IACtHR substitutes the Supreme Court, or that its jurisprudence must be uncritically applied. But [judges should strive to] always favor the person by enforcing norms or interpretations of those norms that prove most favorable. ${ }^{41}$

With the intention of ameliorating those tensions Radilla brought to the surface, judges in the majority used another case to concede that IACtHR decisions do not trump the constitution, thus preserving parts of the old hierarchy. ${ }^{42}$ Consistent with the ethos of communicative entrepreneurship, the IACtHR did not protest this move to establish narrower boundaries for the obligations arising as a result of the conventionality review doctrine.

Radilla thus led to a clearer operationalization of judges' international obligations, and catalyzed a change in interpretive habits via a rise in citations of IACtHR jurisprudence. In fact, over 50 percent of citations of Inter-American jurisprudence between 1994 and 2012 were made during the three-year period following the nudge (2010-2012). The change also affected lower courts. In a survey of 141 federal judges conducted in 2015, 70 percent reported upholding myriad fundamental rights since 2010, with the aid of the conventionality review (Ansolabehere et al. 2018). For example, judges began to rely on IACtHR jurisprudence to limit the jurisdiction of military courts, with important implications for cases of contemporary human rights violations. This is why some crimes perpetrated by the army during the "war on drugs," such as the 2014 Tlatlaya massacre that ended with the brutal execution of 22 people, are being tried in civilian

\footnotetext{
${ }^{41}$ Ibid.

42 293/2011 (2013)
} 
courts. This dramatically increases the chances of favorable outcomes for the victims of state violence, something unimaginable just a few years ago. ${ }^{43}$

To summarize, by engaging in communicative entrepreneurship the IACtHR summoned Mexican judges to a conversation many of them originally refused to have. The clarion call coming from Costa Rica was hard to ignore, even for the old guard. Without communicative efforts it certainly would have taken longer for Mexican judges to begin to regulate the status of international jurisprudence, and apply it more frequently. Importantly, The IACtHR gave Mexican judges the room to contribute to the development of new standards as they saw fit.

\section{Colombia}

The communicative entrepreneurship of the IACtHR also intensified the debate about the status of international jurisprudence in Colombia. Compared to Mexico, however, the context was vastly different, not least because Colombia's Constitutional Court has always been open to international law. Greater openness notwithstanding, communicative entrepreneurship was still instrumental in overcoming reluctance to regulate the influence of Inter-American precedents. This suggests that as a mechanism of norm construction, communicative entrepreneurship was productive under a variety of conditions.

Colombia's 1991 constitution created a Constitutional Court, recognized new fundamental rights, and constitutionalized human rights treaties. Inspired by this architecture, the Constitutional Court has produced world-famous rulings demanding the redesign of public policies, with far-reaching budgetary and political implications (García-Villegas and Uprimny 2004; Rodríguez-Garavito 2011). One of the formulas

\footnotetext{
${ }^{43}$ For a discussion, see Gonzalez-Ocantos (2016).
} 
developed to justify this rights-oriented jurisprudence is the "constitutionality block" doctrine, according to which laws subject to constitutionality tests must be read in light of international law (Uprimny 2008). Anchoring arguments in international law constitutes "a core part of the Court's assertion of power" (Landau 2015, 155-156) because it allows it to legitimize controversial decisions.

The development of the constitutionality block since the mid-1990s, however, did not automatically raise the profile of Inter-American precedents. Citations were almost non-existent until the 2000s. According to a former clerk, "the majority believed that in order to cement its authority the Court ought to find its own voice." $" 44$ Several interviewees also mentioned lack of familiarity and highlighted the arrival of the Internet as a game changer. Another factor contributing to this neglect was the mismatch between the causes each court championed in the 1990s: whereas Colombia's Constitutional Court addressed socio-economic rights, the IACtHR focused on transitional justice. ${ }^{45}$ When transitional justice cases reached the Constitutional Court in the mid-2000s, though, Inter-American precedents became more useful: "This topic was alien to us, so relying on Inter-American jurisprudence proved crucial. $" 46$

By the time the IACtHR turned to communicative entrepreneurship, admittedly, the neglect of Inter-American precedents in Colombia was less severe than in Mexico. But there were still important challenges. In terms of institutionalizing the influence of human rights jurisprudence, the problem was less the absence of citations than the ways usage remained opportunistic. In 2000 the Constitutional Court authorized the use of Inter-American jurisprudence to define the content of fundamental rights, but did so briefly and vaguely (C-010/2000). As a

\footnotetext{
${ }^{44} 22$ August 2016

${ }^{45}$ Interviews: former judge (24 August 2016), former clerk (19 August 2016), clerk (29 August 2016).

${ }^{46}$ Former clerk, 18 August 2016
} 
result, judges "still didn't have any certainty about the rules relative to the incorporation of this jurisprudence." 47 The outcome was an "instrumental use of international law" 48 when judges needed to additional firepower, or "as a sign of cosmopolitanism and erudition. ${ }^{\prime 49}$

A former judge explained that "finding the right formula took time" because of treaty silence on this point. ${ }^{50}$ Exacerbating this was that "citing jurisprudence is more complex than citing treaties. One is always more fearful when interpreting another court because it is hard to identify clear decision rules." ${ }^{51}$ At the heart of the matter, however, were concerns about the distribution of power inside the Court, and between the Court and the IACtHR. Not regulating the practice meant sidestepping a thorny issue:

Self-regulation on these matters is unlikely because power is at stake. On the one hand, forging a consensus among constitutional judges is difficult because this source of law bolsters the power of those with more progressive positions. It is no secret that the IACtHR favors pro-rights criteria. On the other hand, the absence of clear rules widens the Court's margin of appreciation in relation to the Inter-American system. My power is greater when I'm free to decide when to use this jurisprudence. ${ }^{52}$

When the IACtHR launched the conventionality review doctrine, the Constitutional Court gradually became less reluctant to face these political and technical challenges. The nudges designed by the IACtHR encouraged Colombian judges to hand down rulings clarifying the authority of international jurisprudence in

\footnotetext{
${ }^{47}$ Former judge, 10 August 2016

${ }^{48}$ Former clerk, 5 August 2016

${ }^{49}$ Former clerk, 10 August 2016

5023 August 2016

${ }^{51}$ Clerk, 4 August 2016

${ }^{52}$ Clerk, 24 August 2016
} 
a number of ways (C-442-11; SU-712-13; C-500-14). First, the Constitutional Court specified that although only decisions against Colombia are mandatory, judges must consider criteria expounded in precedents against other countries, and if necessary, provide reasons for departing from them. Second, the Court indicated that the conventionality review did not imply an automatic transplant of Inter-American criteria. A precedent only had domestic implications when judges could find unequivocal similarities in the facts of the cases. Moreover, judges had to evaluate whether the domestic legal order already offered adequate protections. If this was the case, it became unnecessary to follow Inter-American jurisprudence. In one ruling, for example, the Constitutional Court was asked to declare the unconstitutionality of libel laws, in line with an Inter-American judgment against Argentina. In turn, the Court explained that its jurisprudence already limited the scope of these laws, rendering unnecessary any attempt to rid them as mandated by the IACtHR. Third, isolated precedents do not constitute sufficient grounds for exercising the conventionality review. The IACtHR must reiterate the same criteria in several cases for its doctrines to become relevant.

Communicative entrepreneurship transformed the choice architecture of Colombian judges, putting a complex issue on the table in a way that made it impossible for them to ignore it. As in Mexico, interviews suggest the decision to participate in scripting the conventionality review was triggered by concerns about the Court's autonomy:

The conventionality review triggered a fierce internal debate. Judges were forced to compromise. In the past it hadn't been necessary to deal with this issue. $^{53}$

\footnotetext{
${ }^{53}$ Clerk, 4 August 2016
} 
The conventionality review was the first attempt by the IACtHR to regulate the conversation [...] Up to that point our jurisprudence had been deferent towards the IACtHR, but only because we were free to be deferent when deference helped us [...] [But] this freedom was put into question, so we started to think more carefully about the status of international precedents. ${ }^{54}$

When the IACtHR puts a name to our international responsibilities, the situation changes. My colleagues chose to start a dialogue of equals to regulate this $[\ldots]$ [Before] it wasn't clear that the IACtHR wanted to regulate the dialogue, so it wasn't necessary to send a message affirming our autonomy. ${ }^{55}$

The constitutionality bloc led to the realization that international law can enrich domestic law. But with the conventionality review we moved from this moment of discovery and awe to a more reactive phase [...] We must preserve our autonomy $[\ldots]\left[\right.$ It's] the only way to rule justly. ${ }^{56}$

In Mexico, nudging was productive because it happened alongside an important constitutional reform. In Colombia, too, the nudge worked in combination with other factors. Interviewees suggest that the conventionality review triggered an intense conversation about the status of Inter-American jurisprudence because the doctrine was launched at a time when Inter-American case law had become more diverse. The more thematic areas covered by the IACtHR, the greater the risk of clashes between courts. Being forced to blindly follow Inter-American criteria on

\footnotetext{
${ }^{54}$ Former judge, 10 August 2016

${ }^{55}$ Judge, 30 August 2016

${ }^{56}$ Judge, 9 August 2016
} 
such a diverse number of issues could also set the Constitutional Court on collision course with domestic actors. The need to regulate the impact of international jurisprudence therefore became more pressing:

Harmony between both courts is no longer guaranteed. When the Court identified this risk, it began to think more carefully about its autonomy. This doesn't mean that we reject the IACtHR. But with the development of the conventionality review we felt the need to establish some rules. ${ }^{57}$

Every time the IACtHR declares that something is in breach of the Convention, it reduces our margin of appreciation. So when the number of IACtHR decisions grows, our degrees of freedom are reduced. If you combine this with the conventionality review, it is only to be expected that we will try to defend our autonomy. ${ }^{58}$

A clerk further explained the Court's reasoning, using the example of a case in which transplanting IACtHR jurisprudence would have led to a conflict with a powerful figure like the Attorney General (SU-712-13):

The fact that the IACtHR could question the Attorney General's prerogatives made our judges stop and think about the legal and political implications of accepting very liberal interpretations [of the reach of Inter-American jurisprudence]. ${ }^{59}$

The Colombian case shows that even courts that are open to international law can be reluctant to regulate the influence of human rights jurisprudence. Communicative entrepreneurship is in this sense an effective mode of norm

${ }^{57}$ Clerk, 25 August 2016

${ }^{58}$ Clerk, 29 August 2016

5924 August 2016 
development that international courts can use to overcome this resistance, and launch a productive conversation. The reaction of the Constitutional Court suggests that a top-down approach would have been counterproductive, possibly resulting in no progress at all in the creation of detailed scripts. Inviting and accepting contributions, by contrast, allowed the IACtHR to engage its local counterpart, and ultimately led to greater clarity regarding the status of international precedents.

Like in the Mexican case, there is nothing in the official record indicating that the IACtHR protested the new Colombian jurisprudence. A mute response is compatible with the notion that it behaved as a communicative entrepreneur, welcoming a collaborative approach to the creation of new behavioral scripts. But this silence is by no means conclusive evidence. When asked about the Colombian case, however, Inter-American judges and clerks did indicate that they did not object to the Constitutional Court's criteria. An Inter-American judge even explained that openness to local views is crucial to improving human rights protections:

To reach just decisions local courts require flexibility [...] The problem with a strict interpretation of the conventionality review is that it can lead to injustice. Establishing clear criteria for the influence of Inter-American jurisprudence is important because it reduces opportunistic usage. But to make these criteria compatible with the human rights cause, we need a dialogue between courts. ${ }^{60}$

\section{Conclusion}

IR scholars have argued convincingly that weak actors can sometimes diffuse technocratic and ethical standards of appropriate behavior, and radically transform state practices and identities. These norm entrepreneurs harbor firm convictions that

\footnotetext{
609 June 2016
} 
allow them to formulate detailed templates and, thus, clearly show others how to modify routine ways of behaving and thinking in order realize moral aspirations and govern better. Scholars, for instance, "point to the objective (non-interpreted) clarity" of the proposed alternative beliefs, organizational forms or technical recipes, as one of the main reasons why norm entrepreneurs succeed (Towns 2011, 31). Clarity and specificity are weapons of the weak because clear messages are easier to transmit. They facilitate the operationalization of abstract values, become focal points that quickly overshadow alternatives, and render less challenging the identification and repudiation of non-compliant behavior during socialization processes (Chayes and Chayes 1993; Keck and Sikkink 1998).

This article offered a new set of conceptual tools for understanding how such international norms develop. I have shown that weak non-state actors do not need this moral and epistemic certainty to succeed in spearheading global scripting exercises. For those who see benefits in regulating behavior in particular social domains, but lack an actionable template ready for propagation, inviting others to talk and creating venues for that conversation to unfold, can be an effective way to set the agenda, secure fresh ideas to figure out what ought to be done, and thus thicken the normative fabric of international society. Put differently, even without the benefits of a clear message that facilitates prescription and persuasion, weak non-state international actors can still transform how states think and behave by promoting discussions via "communicative entrepreneurship". New international institutions trying to find their bearings on the world stage, or seeking to routinize precise rules of engagement with states, as well activists who forecast or detect new challenges for which expert, technical or political solutions are yet to be found, are likely to find this mode of engagement attractive. 
The concept of communicative entrepreneurship also calls attention to the fact that norm development is sometimes open-ended and successful scripting can be highly contingent on the ways in which key players interact. In this sense, the model contributes to the literature that emphasizes the dialogic dimension of norm cycles. For example, Sandholtz (2008) shows that the application of general principles to concrete situations, triggers public arguments that lead to cycles of norm change. Similarly, Risse (2000) argues that dialogue can transform how states' perceive their interests and identities in unexpected ways through a process of "argumentative selfentrapment." According to Deitelhoff $(2009,44)$, this is partly because moving away from bargaining, and closer to a conversation, "changes the underlying power structure of negotiations," increasing the susceptibility of states to the influence of weaker non-state actors. But unlike these approaches - which tend to see dialogue, and its transformative role, as a function of the structural features of the public forums in which international politics unfolds (according to Risse (2000, 33), "public spheres enabling challenges and counterchallenges to validity claims also exist in many issueareas and regions of the world") - "communicative entrepreneurship" provides an agentic perspective in which dialogue is explicitly promoted, and facilitated, by specific players. Dialogue is consequently not a factor that explains, for example, how norms evolve (Sandholtz 2008), or the influence of weak actors (Risse 2000; Deitelhoff 2009), but a deliberate mode of engagement deployed under conditions of uncertainty.

I illustrated "communicative entrepreneurship" using the case of the IACtHR, and its attempt to regulate the use of international jurisprudence by national courts. For an institution virtually ignored during its first 25 years of existence, this was not merely a procedural matter. It was rather a crucial objective designed to solidify its 
influence over the development of regional human rights protections and ensure that the tentacles of Inter-American jurisprudence could benefit victims of state abuse - all without the need for lengthy international litigation battles. The lack of a clear behavioral script to challenge and reform existing judicial habits could have undermined the project from the start. But the skillful deployment of nudges and networking strategies constructed the space, and the willingness, to debate a complex issue. The testimonies of local judicial actors support the view that communicative entrepreneurship indeed rattled local courts and encouraged their participation in the scripting exercise. In Mexico, it led to an unprecedented level of attention to human rights standards. In Colombia, greater precision regarding the conditions under which international jurisprudence is binding also represents progress. Litigants now know how they ought to argue cases if they want to claim the protection of Inter-American rulings.

Contrasting the behavior of the IACtHR in the area of transjudicial communication, with its behavior in the propagation of the norm against impunity, underscores the importance of uncertainty as a catalyst of communicative entrepreneurship. The issue of transjudicial communication had never been seriously debated before the IACtHR introduced the conventionality review doctrine, and continued to be marred with uncertainty afterwards. Whether amnesty laws favoring the perpetrators of egregious human rights violations are acceptable, by contrast, was a debate which had received a great deal of attention before the IACtHR's famous interventions in this norm cycle. During the 1990s, the Latin American human rights community produced a clear normative script that established the extent of states' responsibilities in the investigation and punishment of serious human rights crimes and formulated a detailed technical basis for rejecting amnesties. For example, an 
influential 1992 report by the Inter-American Commission of Human Rights, as well as the work of domestic NGOs and lower courts, especially in Argentina, operationalized the anti-impunity norm, turning the moral repudiation of amnesties into an actionable legal template (Sikkink 2011; Lessa and Payne 2012; GonzalezOcantos 2016). Resultantly, the IACtHR chose a very different mode of engagement than that used to instigate norms of transjudicial communication. In a remarkable stream of rulings starting in 2001 against Peru, Chile, Brazil, and Uruguay, the Court pushed for the adoption of this clear behavioral template, calling for the nullification of amnesties, and for states to support investigations and punish the perpetrators (Davis 2014).

Communicative entrepreneurship also played a role in promoting norms of transjudicial communication, and in solidifying the authority of international courts, outside the Inter-American system. In fact, the model aptly describes the behavior of the European Court of Justice (ECJ) at a critical point in its history, suggesting the concept travels beyond the case at hand and applies to non-human rights courts. The ECJ, created in 1952 to ensure the even application of European law across members of the European Economic Community, used communicative entrepreneurship to reduce uncertainty surrounding the legal status of its judgments and its relationship with national judges. The ensuing scripting exercise became a pillar of European legal integration.

The "preliminary ruling" mechanism in the Treaty of Rome established an official channel for transjudicial communication, allowing national courts to seek ECJ advice on questions of European law. But in the 1960s, when the ECJ developed an interest in routinizing these referrals to expand its opportunities to interpret European law (and its authority), this mechanism was still an obscure clause. Local courts had 
hardly considered using it (Alter 2001). In addition, the place of European law in domestic legal systems was far from clear. To overcome judicial ignorance on these issues, and to begin reducing uncertainty about the parameters of legal integration, the ECJ began cautiously to deploy jurisprudential nudges to incentivize referrals. Some of its rulings were "carefully crafted appeals to judicial ego" (Burely and Mattli 1993, 63), aimed at luring national courts. The ECJ presented itself as the "protector of the prerogatives of lower national courts" (ibid, 64), ruling that certain issues were to be resolved in an exclusive dialogue between them and the ECJ. In addition, the ECJ planned outreach activities to engage judges in discussions about how to operationalize referral practices (Burely and Mattli 1993, 58-62; Helfer and Slaughter 1997, 303). Like in the Americas, nudging and networking ultimately transformed the choice architecture of national courts and promoted reactions from local actors that ultimately led to the development of scripts that created plausible paths for judges to engage with European law.

\section{Supplementary Information}

Appendix A can be found at: https://www.politics.ox.ac.uk/academic-staff/ezequielgonzalez-ocantos.html, as well as at the International Studies Quarterly data archive. The Appendix includes detailed information about citation trends in the rulings of 13 Latin American high courts.

\section{References}

Acharya, Amitav. 2013. "The R2P and Norm Diffusion: Towards a Framework of Norm Circulation." Global Responsibility to Protect, 5:466-479 
Alter, Karen. 2001. Establishing the Supremacy of European Law. Oxford: Oxford University Press.

Ansolabehere, Karina. 2010. "More Power, More Rights? The Supreme Court and Society in Mexico." In Cultures of Legality, edited by Javier Couso, Alexandra Huneeus, and Rachel Sieder. Cambridge: Cambridge University Press.

Ansolabehere, Karina, Sandra, Botero, and Ezequiel Gonzalez-Ocantos (2018) “Conceptualizing and Measuring Legal Cultures: Evidence from a Survey of Mexican Judges.” Unpublished Manuscript.

Bahdi, Reem. 2002. "Globalization of Judgment: Transjudicialism and the Five Faces of International Law in Domestic Courts.” George Washington International Law Review, 34(3):555-603

Benvenisti, Eyal. 1993. "Judicial Misgivings Regarding the Application of International Law.” European Journal of International Law, 4:159-183

Black, Ryan, and Lee Epstein. 2007. "(Re-)setting the Scholarly Agenda on Transjudicial Communication.” Law and Social Inquiry, 32:789-807.

Brunee, Jutta and Stephen Toope. 2010. Legitimacy and Legality in International Law: An Interactional Account. Cambridge: Cambridge University Press

Burley, Anne-Marie and Walter Mattli. 1993. "Europe Before the Court: A Political Theory of Legal Integration.” International Organization, 47:41-76.

Cao, Xun. 2010. "Networks as Channels of Policy Diffusion: Explaining Worldwide Changes in Capital Taxation.” International Studies Quarterly, 54(3):823-854 
Capie, David. 2008. "Localization as Resistance: The Contested Diffusion of Small Arms Norms in Southeast Asia.” Security Dialogue, 39(6):637-658

Cepeda, Juan. 2006. Polémicas Constitucionales. Bogotá: Legis

Chayes, Abram, and Antonia Chayes. 1993. "On Compliance.” International Organization, 47(2):175-205

Checkel, Jeffrey. 2001. "Why Comply? Social Learning and European Identity Change.” International Organization, 55(3):553-588

Couso, Javier. 2010. "The Transformation of Constitutional Discourse and the Judicialization of Politics in Latin America." In Cultures of Legality, edited by Javier Couso, Alexandra Huneeus, and Rachel Sieder. Cambridge: Cambridge University Press

Cortez, Josafat. 2017. "Cambios en las decisiones de la SCJN en materia de DDHH." Ph.D. Dissertation, FLACSO-Mexico

Davis, Jeffrey. 2014. Seeking Human Rights Justice in Latin America. Cambridge: Cambridge University Press.

Deitelhoff, Nicole. 2009. "The Discursive Process of Legalization: Charting Islands of Persuasion in the ICC Case.” International Organization, 63(1):33-65.

Dulitzky, Ariel. 2015. "Inter-American Constitutional Court? The Invention of the Conventionality Control by the Inter-American Court of Human Rights." Texas International Law Journal, 50:45-91

Engstrom, Par, editor (2018) The Inter-American Human Rights System: Impact Beyond Compliance. New York: Palgrave Macmillan 
Ferrer-MacGregor, Eduardo. 2015. "The New Doctrine of the Inter-American Court of Human Rights.” AJIL, November, 93-99

Finnemore, Martha. 1993. "International Organizations as Teachers of Norms: The UNESCO and Science Policy.” International Organization, 47(4):565-597.

Finnemore, Martha, and Kathryn Sikkink. 1998. "International Norm Dynamics and Political Change.” International Organization, 52(4):887-917.

García-Villegas, Mauricio, and Rodrigo Uprimny. 2004. Corte Constitucional y emancipación social en Colombia. Bogota: Norma

Greenhill. Brian. 2010. "The Company You Keep: International Socialization and the Diffusion of Human Rights Norms." International Studies Quarterly, $54(2): 127-145$

Gonzalez-Ocantos, Ezequiel. 2016. Shifting Legal Visions: Judicial Change and Human Rights Trials in Latin America. Cambridge: Cambridge University Press

Goodman, Ryan, and Derek Jinks. 2013. Socializing States. Oxford: Oxford University Press

Habermas, Jurgen. 1984. The Theory of Communicative Action. London: Heinemann 1996. Between Facts and Norms. Cambridge: Polity Press

Hawkins, Darren. 2004. "Explaining Costly International Institutions: Persuasion and Enforceable Human Rights Norms.” International Studies Quarterly, 48(4):779-804 
Hawkins, Darren, and Wade Jacoby. 2010. "Partial Compliance: A Comparison Between the European and Inter-American Courts of Human Rights.” Journal of International Law and International Relations, 6(1):35-85

Helfer, Laurence, and Karen Alter. 2009. "The ATJ and Its Interlocutors: Understanding Preliminary Reference Patterns in the Andean Community." NYU International Journal of Law and Politics, 41:871-930

Helfer, Laurence, and Anne-Marie Slaughter. 1997. "Toward a Theory of Effective Supranational Adjudication." Yale Law Journal, 107:272-386

Hilbink, Lisa. 2007. Judges Beyond Politics in Democracy and Dictatorship. Cambridge: Cambridge University Press.

Hillebretch, Courtney. 2014. Domestic Politics and International Human Rights Tribunals. Cambridge: Cambridge University Press.

Huneeus, Alexandra. 2011. "Courts Resisting Courts: Lessons from the InterAmerican Court's Struggle to Enforce Human Rights." Cornell International Law Journal, 44:493-533

. 2016. "Constitutional Lawyers and the Inter-American Court's Varied Authority." Law and Contemporary Problems, 79:179-207

Johnston. Alistair. 2001. "Treating International Institutions as Social Environments." International Studies Quarterly, 45(4):487-515

Keck, Margaret, and Kathryn Sikkink. 1998. Activists Beyond Borders: Advocacy Networks in International Politics. Ithaca: Cornell University Press.

Landau, David. 2015. "Beyond Judicial Independence: The Construction of Judicial Power in Colombia." Ph.D. Dissertation, Harvard University. 
Lessa, Francesca, and Leigh Payne, editors. 2012. Amnesty in the Age of Human Rights Accountability. Cambridge: Cambridge University Press.

Lopez-Medina, Diego. 2004. Teoría impura del derecho. Bogota: Legis

Magaloni, Ana. 2007. "Por qué la Suprema Corte no ha sido un instrumento para la defensa de los derechos fundamentales?” Working Paper, CIDE

Magaloni, Beatriz. 2003. "Authoritarianism, Democracy and the Supreme Court.” In Democratic Accountability in Latin America, edited by Scott Mainwaring, and Christopher Welna. Oxford: Oxford University Press.

. 2008. "Enforcing Autocratic Political Order and the Role of Courts: The Case of Mexico." In Rule by Law, edited by Tom Ginsburg, and Tamir Moustafa. Cambridge: Cambridge University Press.

Martin, Lisa, and Beth Simmons. 1998. "Theories and Empirical Studies of International Institutions.” International Organization, 52(4):729-757

Milewicz, Carolina, and Robert Goodin. 2016. "Deliberative Capacity Building Through International Organizations.” British Journal of Political Science

Muller, Harald. 2004. "Arguing, Bargaining and All That: Communicative Action, Rationalist Theory and the Logic of Appropriateness in International Relations." European Journal of International Relations, 10(3):395-435

Muller, Amrei. 2017. Judicial Dialogue and Human Rights. Cambridge: Cambridge University Press.

Nunes, Rodrigo. 2010. "Ideational Origins of Progressive Judicial Activism." Latin American Politics and Society, 52(3):67-97 
Pasqualucci, Jo. 2013. The Practice and Procedure of the Inter-American Court of Human Rights. Cambridge: Cambridge University Press

Payne, Rodger. 2001. "Persuasion, Frames and Norm Construction." European Journal of International Relations, 7(1):37-61

Percy, Sarah. 2001. "Mercenaries: Strong Norm, Weak Law." International Organization, 61(2):367-397

Risse, Thomas. 2000. "Let's Argue! Communicative Action in World Politics." International Organization, 54:1-39

Risse-Kappen, Thomas, Stephen Ropp, and Kathryn Sikkink, editors. 1999. The Power of Human Rights. Cambridge: Cambridge University Press

Rodríguez-Garavito, Cesar. 2011. "Beyond the Courtroom: The Impact of Judicial Activism on Socioeconomic Rights in Latin America." Texas Law Review, 89:1969-1977

Sandholtz, Wayne. 2008. "Dynamics of International Norm Change: Rules Against Wartime Plunder.” European Journal of International Relations, 14(1):101131 . 2015. "How Do Domestic Courts Use International Law?" Fordham International Law Journal, 38:595-636

Sandholtz, Wayne, and Kendall Stiles. 2009. International Norms and Cycles of Change. Oxford: Oxford University Press.

Shany, Yuval. 2007. Regulating Jurisdictional Relations Between National and International Courts. Oxford: Oxford University Press

Sikkink, Kathryn. 2011. The Justice Cascade. New York: Norman 
Simmons, Beth, and Zachary Elkins. 2004. "The Globalization of Liberalization: Policy Diffusion in the International Political Economy." American Political Science Review, 98(1):171-189

Slaughter, Anne-Marie. 2004. A New World Order. Princeton: Princeton University Press.

Thaler, Richard, and Cass. Sunstein. 2008. Nudge. London: Penguin

Towns, Ann. 2010. Women and States: Norms and Hierarchies in International Society. Cambridge: Cambridge University Press

Uprimny, Rodrigo. 2008. Bloque de constitucionalidad, derechos humanos y proceso penal. Bogota: Consejo de la Juricatura

Valencia, Carlos. 1990. "Legislación y jurisprudencia colombiana en relación con los instrumentos internacionales de protección de derechos humanos." In Espacios internacionales para la jusiticia colombiana, edited by Gustavo Gallón. Bogotá: CAJ

Voeten, Eric, and Laurence Helfer. 2014. “International Courts as Agents of Legal Change: Evidence from LGBT Rights in Europe.” International Organization, $68: 77-110$ 